Original Article (short paper)

\title{
The women inclusion on rugby: perceptions of Brazilian national team players
}

\author{
Flavia Volta Cortes de Oliveira ${ }^{1}$, Helena Altmann ${ }^{1}\left[\right.$, Renato Francisco Rodrigues Marques ${ }^{1,2}(\mathbb{E}$ \\ ${ }^{1}$ Universidade Estadual de Campinas, Campinas, SP, Brasil, ${ }^{2}$ Universidade de São Paulo, Ribeirão Preto, SP, Brasil
}

\begin{abstract}
Aims: Women participation in sport is historically permeated by manifestations of discrimination, especially in male preserve practices. This study aimed to investigate and describe the processes of entry and performance of women athletes in rugby, as well as socio-cultural components of this field in relation to gender differences from the perspective of Brazilian women national senior team players. Methods: Semi-structured interviews with five athletes were performed and data analyzed based on the Grounded Theory method. Results: It was found that there are social barriers for women practice in rugby. By the other hand, better opportunities for the development of an athletic career are more available than in the past. Besides that, it has been perceived that the women players need to constantly prove that they can play hard to legitimize their athletic skills among men players. Conclusions: Even if the women participation in rugby is in a changing process of acceptance, barriers still need to be broken for a full social legitimation of these players' practice.
\end{abstract}

Keywords: rugby; femininity; gender; sociology; women sport.

\section{Introduction}

Gender issues historically permeate women participation in sports. The naturalized representation that men and women stand out as masculine or feminine regarding different body characteristics, sustained unequal relations and justified different social insertions for both ${ }^{1}$.

During the end of the twentieth century and beginning of the twenty-first, the word 'gender' has been used as social relations between biological sexes. Conceptually, gender can be understood as a way of classifying a socially agreed phenomenon, and not just as an objective description of innate characteristics ${ }^{2}$.

The word 'gender' is commonly used related to the masculine/ feminine distinction as well as the constructions that separate both bodies. This is because society helps to structure not only personality and behavior but also how bodies manifest themselves. Thus, sex and gender are not independent elements ${ }^{3}$.

Certain gestures, body movements, clothes, and even the muscular formation of individuals carry with them meanings, which socially are associated with masculine or feminine, and are often justifications for the entry, adhesion, and permanence or not of men and women in some sports. This leads to the belief that those features already born linked to biological sex, and that would determine behaviors, social functions and belonging places for men and women ${ }^{1}$.

Despite the increase of women's participation in sports during the last years, it is still a field where women's achievements are less legitimated than $\mathrm{men}^{4}$. In addition, it is possible to perceive certain aesthetic appreciation of the athletes' bodies, which means that, often, even proving their competence as athletes, physical attributes seem to be more important, facilitating or even making possible higher-level achievements in sports. This can include fame and publicity contracts, which leads their athletic performances to a secondary level.

In rugby, as well as in soccer, the arising of the use of corporal violence is considered genuine, mainly because of the combat representation or the simulated confrontation between two individuals or teams. Originally, in these sports, there were no written rules, the games took place on the streets or fields, and the high level of aggressiveness was an essential feature of the game. These games were related to the structure of European society from the fifteenth to the seventeenth centuries, in which violence was deeply present in people daily lives when the balance of power between men and women was strongly favorable to men. Thus, these games were an expression of the patriarchal culture, which enforced stereotyped masculine expression, which was the representation of the ideal man. On the other hand, for women was attributed to the feminine ideal of fragility, timidity, and dependence ${ }^{6}$. The emphasis on competition, especially in team sports, where the dimensions of combat and confrontation are more visible, end up as a good environment to create and legitimate male preserve spaces ${ }^{4,7}$.

The term "male preserve" was first used as a reference to rugby clubs in the 1970s, in order to conceptualize it as a social setting for the expression of norms of masculinity for the middle and upper English classes. These norms were derived from the ethos of an elite with military roots, source, and ground of the English concept of the gentleman. Between the years of 1850 and 1870 , rugby began to be considered as a game which 
provided to a young man the opportunity to engage in vigorous physical activities, which have been denied to them in other fields of society. Women, in a discriminatory and stereotyped way, would not fit into these sports, since they assume strength, endurance and aggressiveness typically attributed to men, and also the rituals have involved the objectification of women ${ }^{7}$.

The modern sports have emerged as part of the civilization process and is better understood as a field of public expression and preservation of traditional standards of masculinity ${ }^{6}$. It helps to understand the resistance to womens' entering and development of abilities in sports. However, it is important to observe and detach changes in the conformations of society that provided new social places for women. In the post World War II era, with all changes in the conformation of workplaces, the decline of family wages and consequent women's gradual movement into the labor force, generate a kind of insecurity and concern about the "society feminization" among men. It is important to mention that the significant shift in the balance of power between men and women had one important public expression in the suffragette movement, that together with the social and economic changes were responsible for a lot of the changes expressed today ${ }^{8}$.

Gender and sexuality have been suffering changes in their meanings over time. Nowadays, it is possible to perceive a transgression process of sexual categories and gender boundaries, destabilizing old and solid certainties, and creating new forms of existence. A new cultural policy of identities has been established in this process, where ethnic, racial and gender minorities begin to demonstrate their disagreement with orthodox and conservatory theories and concepts, seeking to build new social practices ${ }^{9}$.

By the end of the twentieth century and the beginning of the twenty-first, with the transformation of several women participation in western society, and an increment of this in sports participation, the acceptance of the women as an athlete came along with the conquest and appropriation of their own body ${ }^{10}$. The lean and strong women body became more valued, relativizing biological arguments about fragility. Even with some cultural transformations, strengthened by expressive results achieved by women in sport, they are currently receiving less media attention, lower salaries and lower rewards compared to men ${ }^{11,12}$.

Despite some achievements, the athletes' struggle continues to come up against cultures of restriction in certain sports practices $^{4,10}$. Thus, women athletes that were pioneers in male preserve practices have shown, throughout history, that changes in women participation in sports have been linked to the processes of the feminist movement, with the conquest of many public places previously only allowed to men ${ }^{13}$.

Rugby is a very popular sport in different countries, especially from that English colonization and, although this sport is not well known in Brazil yet, it is becoming more popular every day ${ }^{14}$. Brazilian women national rugby team has been reaching very expressive results recently, as for example the South American championship title, followed by around twelve other consecutive titles. These achievements provided their participation in the 2009 and 2013 world championship. In addition, they won a bronze medal in 2015 Pan American games and reached the ninth place in 2016 Rio de Janeiro Olympic Games. In 2018, they won the South American Championship, guaranteeing a place for the 2019 Pan American Games. Despite the fourth place in this later tournament, the women's national rugby Brazilian senior team is known as the best Latin American one, ahead of Argentina, Uruguay and Chile, countries where rugby is much more popular than in Brazil ${ }^{15,16,17}$.

Through such historical processes, which arbitrarily attribute the symbolism related to rugby as a male preserve sport, it is possible to notice that women participation is a recent event that still brings strangeness to some spheres of society ${ }^{12}$. As exposed, to understand how women Brazilian rugby team players perceive feminine participation, the aim of this study was to investigate and describe the processes of entry and performance of women in rugby, as well as socio-cultural components of this field in relation to gender differences from the perspective of athletes.

\section{Methods}

A qualitative research approach was held, using Grounded Theory as the methodological option ${ }^{18,19}$. This method has its fundaments on the construction of a theory based on produced data and not on previous hypotheses, being essential that the collection and analysis occur at the same time. For this study, data were produced from semi-structured interviews with athletes of Brazilian women rugby national team.

In Grounded Theory, it is not possible to pre-establish the number of participants that will be part of the research, and data collection conclusion occurs according to the reach of the theoretical sampling or by the limit of access to participants ${ }^{19}$.

The participants of this study were selected according to the following criteria: a) has already participated in training and/or matches of the Brazilian women rugby national senior team; b) has 18 years old completed until the date of interview. The choice for Brazilian national team athletes was due to their detached position in this sport and, for this reason, they attend to many places that can provide a large number of experiences in this field.

The contact with athletes was made through the support of the Brazilian Rugby Confederation (CBRu - Confederação Brasileira de Rugby) that indicated the dates and place for the interviews, as well as the athletes who would participate in the research, according to their availability.

The interviews carried out at NAR - Núcleo de Alto Rendimento do Grupo Pão de Açúcar in São Paulo/SP, Brazil, during a team's training season. The interviews were conducted individually, in a private room, in a single day during the intervals of the athletes' training periods. Five athletes have participated voluntarily and were named as P1, P2, P3, P4, and P5, to preserve their identities.

The present study was submitted and approved by the Ethics Committee of the School of Physical Education and Sport of Ribeirão Preto - University of São Paulo, under the register, CAAE: 14239113.6.0000.5407. All participants read and signed the Informed Consent Form. 


\section{Results and discussion}

When athletes were asked about practicing a male preserve sport, they generally reported that considered it more virile than others. They believe that in Brazil, rugby does not represent as a 'men sport that women practice', but as a sport of strength and hard body contact that has been practiced by men and women. This, according to P2, differs from other countries where rugby is a historical men sport. The athletes consider as normal the practice of a sport with hard physical contact, especially because they have always been involved in activities with similar requirements during their sports career ${ }^{[1]}$. All the participants consider that is possible to be feminine and play rugby at the same time.

I have never faced it as a men sport, but as a more virile sport, where you need to have the strength and develop it (P1).

I believe that in Brazil [...] rugby is raising now; it is obvious that for decades the rugby exists in Brazil, but now it is appearing and making sense for the public. Rugby was not considered an exclusive men sport that women have invaded and began to practice; it is a sport that men and women practice equally (P2).

These data corroborate to Almeida' $\mathrm{s}^{20}$ ethnographic study with rugby players in Porto Alegre/RS, Brazil, in which athletes faced the fact that they often leave the field dirty, bruised and with pains as something expected and valued. Even after a match in which the athletes leave under these conditions, they are still satisfied. For them, the bravery, strength, and commitment do not prevent them from being feminine.

It is possible to perceive a similar discourse between interviewed players in this study and those presented by Almeida ${ }^{20}$. Those athletes define rugby as a virile, but not masculine, sport in which the participants are required to have the courage, commitment, feeling pain and bruising, but always maintaining their femininity. The same perception was described by elite women futsal (other sport that can be considered as a male preserve in Brazil) players in the state of São Paulo, Brazil ${ }^{21}$.

Another topic produced from interviews was the relationship between rugby and violence. For the interviewed athletes, people outside of rugby environment commonly believe that this sport is related to violence due to constant and hard body contact.

In the beginning, you suffer [prejudice and discrimination] because people do not understand your choice [for playing rugby] [...] I believe that

\footnotetext{
${ }^{1}$ For more information, please consult: Oliveira, FVC; Menezes, RP \& Marques, RFR. Trajetória esportiva de jogadoras da seleção brasileira feminina de Rugby: vivências diversificadas na infância e a especialização tardia na modalidade. In: Galatti, LR; Scaglia, AJ; Montagner, PC \& Paes, RR. (Ed.). Desenvolvimento de treinadores e atletas: Pedagogia do Esporte. Campinas: Editora da Unicamp, 2017, pp. 235-251.
}

it happens because of the corporal contact [...] the action of "putting our own body in risk" (P5).

It is a different sport, with very specific rules. The question is not to discuss whether it is a more masculine or feminine sport, but I believe that because of the contact which is considered as a violent and brutal game (P1).

Such perspective permeates the construction of an idealization on the rugby player's body and the relationship with intense physical contact, often considered violent or aggressive for the women body. In fact, Elias and Dunning ${ }^{6}$ suggest, from the roots of rugby in the nineteenth century, characteristics like contact and confrontation with the opponent, that suit to demonstrate strength and courage. These characteristics were important to create a male reputation related to this sport. The idea of virility does not cease to exist in the present days, but the perception about gender can, historically, undergo transformations ${ }^{22}$.

The references to body shape, effectiveness, and functioning have changed over time, with uncountable ways of referring and representing it. This diversity is abundant within each culture and time ${ }^{22}$. It helps to understand the estrangement of those who are not involved within rugby, caused by their relationship to the confrontation, historically related to the strong and masculine body, and not to the feminine, being this later considered as a fragile body. In addition, this relationship has changed with the insertion of women in these environments, collaborating with many notions of virility and femininity.

All the social changes and insertions of women in those sports have brought gains regarding self-concept, a greater feeling of security in public spaces and greater ability to defend themselves. The desire for equality with men is a result of frustrations over the limited traditional feminine roles. Women are making strides in sports once considered categorically inappropriate ${ }^{8}$. The players' discourses show a different relationship with their own body, very focused on the efficiency demanded by the sport. This relationship, as P5 argues, when using the expression "put our own body in risk" demonstrates another way to manifest herself as a woman, an athlete woman.

The strangeness and prejudice about women participation in sport was another theme that emerged from interviews. According to the athletes, society still strange a woman practicing any kind of sport, which is reinforced by several other studies ${ }^{23,24,21}$. Most of the interviewees claim that they still have to conquer social spaces. They believe that women sport is marginalized when compared to men, because a woman is not culturally expected to be an athlete. Other studies in Brazil ${ }^{12,24}$ show that women sport seems to have less commercial appeal and often its disclosure is more related to the athletes' aesthetic aspects than to their athletic achievements, what could make the beauty as secondary. This perspective echoed in the discourse of some participants of this study.

A woman, when she is born, receives a doll as a gift, and when a man is born, a soccer ball. I kept saying 
this to my students: why don't you know how to kick [the ball] while the boys do? Because you could not do it, you had to learn to wash the dishes [in childhood] and they did not [...] Society is sometimes not ready for the woman who has muscles. Nowadays, it is more accepted because of the fitness culture. However, it was not always like this. Therefore, it was a bias, because the girl was not in the place they wanted to be, the little flower that could break and had to be protected by the man. By the other hand, it is a process, and women are evolving on this. The woman who previously could not work, today works, it is one thing, it is not specific to rugby as well, it is an evolution of the society itself, women who play sports (P2).

Those discourses show a scenario of conflicts. At the same time, the interviewed players assume that women participation is common in the rugby field, describing that lay people still demonstrate strangeness with the presence of women in a sport culturally considered as virile, violent and intense.

This conflict can be a sign of a transformation process of the femininity within the sports field, which has begun as a preserved space for men and, in the course of history, has been witnessing a process of openness to women participation.

As reported by $\mathrm{P} 2$, girls are often introduced to doll plays, household chores, unlike boys who are always in contact with ball games and running. The construction of genders and sexualities takes place through numerous learning processes and practices. They are shown in the most varied situations, and it is proposed explicitly or not by a set of social and cultural instances that is inexhaustible. Thus, it can be said that this is an always unfinished, constantly changing process. In this scenario, the most diverse social institutions influence this construction: the family, the school, the church, among countless other issues and institutions ${ }^{9}$. Still, according to P2, it is an evolution of society, women practicing sport.

In fact, it is a recent phenomenon of women highlighting within the sports field. The struggle of this contemporary woman to become a protagonist in several fields of society comes in part from the growth of the feminine identification with the imaginary of the warrior and the process of social transformation of the positions occupied by them. This changing culminated on the increment of women participation in sport, and achievements related to the appropriation of the body that contributes to the income of the social acceptance of the women athlete ${ }^{11}$.

According to P5, in rugby clubs, men often consider that women are playing for personal relationships, to lose weight and fat, or with other interests different from sport, sometimes being badly seen to drink alcohol in the third time ${ }^{[2]}$. Despite this, the interviewed players believe they suffer less prejudice than other because they are part of the Brazilian national senior team, and suggest that within the clubs, the discrimination is greater to other women players that were not part of this national team.

\footnotetext{
${ }^{2}$ Third time is the celebration that traditionally happens after the rugby match, in which the opposing teams meet to celebrate the end of the game and comment on the events, leaving aside the rivalry. It is a common practice in the social environment of rugby.
}

I think, in the clubs, the women [players] suffer a little bit more, do you know what I mean? The women seem to be a subcategory. It is always left out, even with the women team's competitive results being usually better than men in some clubs. Women can have a faster pathway to the national senior team [in comparison to men] [...] There is a lack of appreciation on the women rugby and the players suffer a lot in the clubs because many men thinking that women are there because they want to date with them. They [men] think women are not there for sport, for love, for culture (P5).

According to Saouter ${ }^{25}$, the third time celebration is one of the moments of greater exclusion of women. It disrupts a masculine celebration, typical of the male rugby culture. Women would invade a space of free expression of exaggerated masculinity, where men can tell eschatological jokes, and still get exaggerated drunk. As reported by P5, men consider that women choose rugby for many reasons that undermine their choice, clearly demonstrating the prejudice over those who dare to enter into sport.

The history of women participation in sports generates resistance since it has been conventionally considered as a privileged space for the construction, affirmation, and expression of masculinity. Also, in rugby clubs, men were able to mock, objectify and defame women, behavior that was denied to them in other fields of society ${ }^{7}$. However, the evolution of social values, and all-feminist movements, such as the suffragette movement, involved the women emancipation in British society, what begins to threat this sport structure. Women started to be accepted and welcome visitors in rugby clubs, and those changes in this sports field includes economic factors and changes in the position of women in the wider society ${ }^{7}$.

It is noticed in P5's discourse a tendency to confront the possibilities of sports career comparing men and women. In addition to this analogy, new explanations have emerged about a difference among genders, and all the interviewees said that the major difference is related to the greater men muscle power when compared to the women muscle strength.

\section{Perhaps because of the physical strength of the} men, women game is different (P2).

I think it is the strength [the reason for differences within the games'styles among men and women]. It is clear that a man is quite different from the women (P3).

Sometimes women sport is also not well valued, because many people consider that it involves less aggressiveness and intensity. Because it is considered different from the men, there is a historical belief that women play sports, but not like men ${ }^{5}$. On a study about women that practice boxing, it was possible to verify a similar perception, since the athletes also report a difference in strength, but believe that there is no big difference concerning struggle since they value technical issues ${ }^{26}$. 
Saouter ${ }^{25}$ points to this idea of the difference between the most virile mode of playing by men versus women being the later's game as less brutal than the first. On the other hand, such differentiation disturbs some men players, because it somehow damages the competitive nature of the rugby. However, it is noted that such speeches of women rugby athletes permeate social constructions of gender, but sometimes there is an indirect reference to the idea that gender is linked to biological sex, reinforcing socially expected stereotypes.

On the influence of media, interviewed athletes said that rugby has always little publicity, but this has been changing in Brazil. There is an increasing on the spread of this sport, from more game appearances on television and more news on that. Even with a great women participation in sports such as judo, handball, soccer, and the great presence in several sports clubs, championships and even in the Olympic Games, this scenario still does not reflect the same disclosure and attention from the media that men sports have ${ }^{27}$.

Since I got into rugby there was not much publicity, we could rarely watch games on television (P4).

Oh, it is very little [the media coverage on women rugby], I always watch TV, sport news and I get angry because $90 \%$ is about soccer (P3).

Women boxing athletes also reported poor visibility of this sport on media, both men and women, but with a marked disadvantage for the later. In addition, it was found from these interviewed athletes that the legitimacy of their achievements comes from media coverage, and also from the insertion and legitimation of the contents of women struggles related to body culture, discourse echoed by other studies ${ }^{24,26}$.

Concerning the content of the reports about rugby, some athletes mentioned that they are in general, evaluated as good quality. However, they said that not always the reports on women rugby are referring to the athletic results achieved and the sporting performance itself. According to them, the men rugby is more valued for being more commercial accepted, and the approach to the women is based on the athletes' aesthetic emphasis, the details like the tattoo, if the nails are made, the hair tidied, among others. This perspective decreases the expectation and appreciation on the players' athletic performances and results.

The media also value more the men because it is more marketable [...] Then the interviews are always "oh, but do you lose vanity?" It is never "how are you as an athlete, how are your struggles to be here?" Do you know what I mean? We are athletes, but before we are women and must to be feminine for the wider public (P5).

Similar phenomena can be observed in the Paralympic sport, where the disabled athlete is portrayed by the media as brave and courageous due to overcoming the limits of the disability. This perspective, although may help to publicize the sport, decreases the symbolic value of their athletic achievements, showing the handicap in detriment of the athletic aptitude, and embodying low expectations as to the individual in the sporting environment $t^{28,29,30}$.

Women athletes have had to fight hard to acquire the prestige that remains bigger for men. Besides that, the low exposure of women sports in the mass media and the relative lower rewards compared to men along with powerful ideologies questioning their femininity or their sexual orientation, and the prediction of possible physical damages, still remain ${ }^{8}$. As mentioned by Adelman $^{31}$, the literature has pointed to a relative lack of women athletes present in the media coverage, as well as the important role these vehicles have in producing meaning about what is to be a woman or to be a man in society. The interviewees of the present study confirm this perspective, declaring that in most of the cases the approaches of the journalists do not take into account the sports performances and results, but mainly the fact that they are women athletes.

There were several times that we talked about interesting topics of the rugby and the journalists talked only about the tattoo of the rugby women players. [...] Nobody took into account that we have won several South Americans National senior teams, that we have reached the tenth place in the world championship (P1).

The media is not a body isolated from society, being a complex web of reception, circulation, and interaction of information, reporting, influencing and being influenced by the manifestations from many social group ${ }^{32}$. However, who receives the news is never immune from partiality ${ }^{33}$. This is how that social phenomenon is reinforced, together with the prejudice with the women sport.

In this scenario, women soccer in the 1970s and 1980s suffered a lot of prejudice in media records. It was possible to observe metaphors that ridiculed the women's presence in the fields. In some reports, the approach to physical beauty was larger than their technical skills, always leading to questioning the true abilities of athletes ${ }^{27}$.

Despite there is this differentiation on how media discourse addresses men and women sports, the positive focus on women athletic performance in the sport environment is recent and grows as women become more socially active and independent. It should not fail to consider examples of women who have reached detachable levels of performance in sport and have been changing this scenario in several contexts as judo, volleyball and even in rugby, where we can perceive very important results won by women Brazilian rugby senior national team ${ }^{12}$. The sport is still seen as a male preserve space and it makes the women athletes important agents to transform this reality ${ }^{11}$.

\section{Conclusions}

This study proposed a reflection about women participation in rugby, from the perspectives of women Brazilian national rugby team athletes. 
Based on the interviewed players' discourses, manifestations related to the discrimination suffered by women have emerged, especially in rugby, mainly related to the use of the body and lack of prestige from media. Some examples are the perceptions and belief that men and women games are different; the media approach is based primarily on aesthetic issues, and; there is prejudice related to the real reasons for the women participation in rugby.

Some barriers that have been exposed still need to be overturned for greater fairness of opportunities for practice, athletic development and career in women sport, compared to men. The main issue seems to be the need of constantly proving their skills and ability to play intensively, searching for a better appreciation of athletic skills in detriment of aesthetic highlights.

Women sport has been receiving less commercial appeal and attention than men, both in rugby as well as in other sports. This social barrier is one of the greater obstacles to be broken by these athletes, who find as strong resistance the cultural traits that prioritize the women image linked to the delicacy, fragility, and athletic incompetence.

Interviewed athletes proposed that discrimination and prejudice are present in the media approach, especially when questions regarding the femininity of athletes, emphasizing primarily the aesthetical beauty and secondarily the achieved competitive results and performance. It is possible that women sport is not so profitable for media, which leads to a process of commercialization of femininity on women athletes. Such events may have support in a stereotyped and prejudiced culture regarding the presence of women in sport.

The perception of discrimination and prejudice is highlighted in the women rugby athletes' discourses, which are part of society as a whole, disclaiming about the pressure from several groups of people about explanations related to the choice for rugby over other sports considered as less virile.

This discrimination is exemplified by men colleagues, which questioning the real women players' interests in attending rugby activities, besides their ability to play. It is quite clear that there are still issues and barriers that need to be overcome, especially related to the value of women agency as more symbolically recognized within sports field.

It is worth mentioning the great importance of the role that each of these athletes plays in sports, as they are fundamental agents in the whole process of changing gender stereotypes and social values present in this context.

This study does not end the discussions about this topic. It is important to highlight the need for further investigations that can deepen the research on other sports and different scenarios of women performance in male preserve practices.

\section{References}

1. Goellner SV. Feminismos, mulheres e esportes: questões epistemológicas sobre o fazer historiográfico. Movimento. 2007; 13 (2): 171-196.

2. Scott JW. Gender and the politics of history. New York: Columbia University Press, 1999.
3. Nicholson L. Interpretando gênero. Revista Estudos Feministas 2000; 8 (2): 9-42.

4. Marivoet S. Aspectos sociológicos do desporto. 2ed. Lisboa: Livros Horizonte, 2002.

5. Coakley J. Sports in society: issues and controversies. 12ed. Saint Louis: Times Mirror/Mosby College Publishing, 2017.

6. Elias N, Dunning E. A busca da excitação. Lisboa: Difel, 1992.

7. Dunning, EG, Sheard, KG. The Rugby Football Club as a Type of "Male Preserve": Some Sociological Notes. International Review of Sport Sociology, 1973;8(3), p.5-24.

8. Dunning E, Maguire J. Process-Sociological Notes on Sport, Gender Relations and Violence Control. International Review for the Sociology of Sport, 1996; 31(3): 295-319.

9. Louro GL. Gênero e sexualidade: pedagogias contemporâneas. Pro-posições, 2008; 19 (2): 17 - 23.

10. Delaney T, Madigan T. The sociology of sports: an introduction. Jefferson: McFarland \& Company, 2009.

11. Mesquita A, Nascimento IS. As possíveis relações entre os feminismos e as práticas esportivas. In: Rubio K. As Mulheres e o esporte olímpico brasileiro. São Paulo, $1^{\mathrm{a}}$ Ed, Casa do Psicólogo; 2011. p. 167-181.

12. Oliveira FVC, Marques RFR. A Percepção das jogadoras da seleção brasileira de rugby sobre a entrada da modalidade nos Jogos Olímpicos: expectativa por maior valorização da modalidade. In: Akmeida MAB. Estudos Interdisciplinares em Sociologia do Esporte. São Paulo, EACH; 2015, p. 111-121.

13. Tralci-Filho MA, Araujo SEC. As possíveis relações entre os feminismos e as práticas esportivas. In: Rubio K. As Mulheres e o esporte olímpico brasileiro. São Paulo $1^{\mathrm{a}}$ ed Casa do Psicólogo; 2011. p. 17-41.

14. Gutierrez, D, Antônio VSR, V, Almeida, MAB. A study on the introduction and institutionalization of rugby in brazil. Journal physical education. 2017; 28: 2841.

15. Confederação Brasileira de Rugby. O Rugby. Available from: http://www.brasilRugby.com.br/ [Accessed 23th October 2013].

16. Portal do Rugby. história do rugby. Available from: www.portaldorugby.com.br/entenda-o-rugby/historia-do-rugby [Accessed 15th October 2017].

17. Brasil Rugby. Available from: https://ww2.brasilrugby.com.br/ blogs/news/selecao-brasileira-feminina-de-7s-conquista-medalha-de-ouro-em-cochabamba-e-garante-vaga-no-pan-2019 [Accessed 26th january 2019].

18. Strauss A, Corbin J. Pesquisa Qualitativa: técnicas e procedimentos para o desenvolvimento de Teoria Fundamentada. $2^{\mathrm{a}}$ Ed. Porto Alegre: Artmed, 2008.

19. Charmaz K. A construção da teoria fundamentada: guia prático para análise qualitativa. $2^{\mathrm{a}}$ Ed. Porto Alegre: Artmed, 2009.

20. Almeida TR. Fortes, aguerridas e femininas: um olhar etnográfico sobre as mulheres praticantes de rúgbi em um clube de Porto Alegre. Porto Alegre. Dissertação de Mestrado [Programa de pós graduação em ciências do movimento humano] Universidade Federal do Rio Grande do Sul; 2008.

21. Mascarin RB, Oliveira FVC, Marques RFR. Feminilidade e Preconceito de Gênero no Futsal: Uma perspectiva de atletas brasileiras. Fluxos \& Riscos. 2017; 2 (2): 83 - 96.

22. Vigarello G. A história e os modelos do corpo. Pro-posições. 2003; 14 (2): 21-29. 
23. Altmann H, Reis HHB. Futsal feminino na América do Sul: trajetórias de enfrentamentos e de conquistas. Movimento. 2013; 19 (3): 211-232.

24. Salvini L, Marchi-Jr W. "Guerreiras de chuteiras" na luta pelo reconhecimento: relatos acerca do preconceito no futebol feminino brasileiro. Rev. Bras. Educ. Fís. Esporte. 2016; 30 (2): 303-311.

25. Saouter A. A mamãe e a prostituta. Os homens, as mulheres e o rúgbi. Movimento. 2003; 9 (2): 37-52.

26. Cardoso BLC, Sampaio TMV, Santos DS. Dimensões socioculturais do boxe: percepção e trajetória de mulheres atletas. Movimento. 2015; 21 (1): 139-154.

27. Mourão L, Morel M. As narrativas sobre o futebol feminino: o discurso da mídia impressa em campo. Rev. Bras. Ciênc. Esporte. 2005; 26 (2): 73-86.

28. Silva CF, Howe PD. The (in)validity of supercrip representation of Paralympic athletes. JSSI. 2012; 36 (2): 174-194.

29. Marques RFR, Gutierrez GL, Almeida MAB, Nunomura M, Menezes RP. Abordagem midiática sobre o esporte paralímpico: o ponto de vista de atletas brasileiros. Movimento. 2014; 20 (3): 989-1015.

30. Marques RFR, Marivoet S, Almeida MABd, Gutierrez GL, Menezes RP, Nunomura M. A cobertura midiática sobre o desporto paralímpico: perspectivas de atletas portugueses. Motricidade. 2015; 11: 123-147.
31. Adelman M. Mulheres atletas: re-significações da corporalidade feminina. Revista Estudos Feministas. 2003; 11 (2): 445-465.

32. Pires GL. Mídia, esporte e ilusão. In: SESC. Fórum Internacional de Esporte e Lazer. Rio de Janeiro, 2006.

33. Bourdieu P. Sobre a televisão. Rio de Janeiro: Jorge Zahar Editor, 1997.

\section{Corresponding author}

Flavia Volta Cortes de Oliveira.

Av. Bandeirantes 3900 - Monte Alegre, Ribeirão Preto. Escola de Educação Física e Esporte de Ribeirão Preto, USP.

Email: flavolta@hotmail.com

Manuscript received on January 29, 2019

Manuscript accepted on July 8, 2019

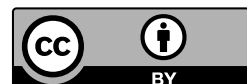

Motriz. The Journal of Physical Education. UNESP. Rio Claro, SP, Brazil - eISSN: 1980-6574 - under a license Creative Commons - Version 4.0 